\title{
Two Instances of Mundus Inversus in Psalm 113
}

A Basson

(University of Stellenbosch)

\section{ABSTRACT}

\section{Two Instances of Mundus Inversus in Psalm 113:7-9}

The psalms often praise Yahweh for his transformative and restorative interventions both in the past and in all times. They portray the deity as the one who offers protection to the weak and defenceless members of society. He uplifts the downtrodden and affords them a place in structure where they gain a new status. In Psalm 113:7-9, Yahweh changes the circumstances of the poor and needy and the childless woman. Social outcasts have their dignity and honour restored. This article explicates these divine acts in terms of the topos of mundus inversus (world-upside down). This cultural phenomenon, which finds expression in artistic, sociopolitical and religious spheres, accentuates the possibility of another reality by inverting the status quo. Psalm 113 praises Yahweh as the incomparable God who inverts the situation of those condemned to a life of suffering. His incomparability is linked with his power to create a mundus inversus in which the poor and needy have a banquet with nobles and a barren woman takes pleasure in motherhood.

\section{INTRODUCTION}

The biblical Hebrew Psalms express the whole gamut of the life experiences of ancient Israel. These lyric poems "reveal all the religious feelings of the faithful - fears, doubts, and tragedies, as well as triumphs, joys, and hopes" (Ross 1985:779). Because they reflect life with all its joy and sorrow, these hymns resonate from the nadir of despair to the zenith of happiness. Not surprisingly, then, praise and lament are prominent features of the psalms, accentuating both the psalmist's exultation at Yahweh's transformative and restorative acts and his disillusionment at the deity's indifference in times of affliction. Because the psalms are rooted in Yahweh's revelation in history, his rule underlies both the petitions and the praises of the psalmists (cf Estes 2005:151). Despite the prevalence of lament, praise reverberates through the psalms. As Anderson (2000:21) observes, "For every psalm, whatever its topology or classification, is actually a song that extols and glorifies God." In 
addition to praising Yahweh for a unique intervention at a specific point in time, the psalmists exalt his mighty deeds in all times and in all places. The deity continuously provides support to those who cry to Him for deliverance from the abyss of suffering and grief. Not surprisingly, then, the lowly and socially marginalised constantly proclaim the grace and majesty of Yahweh. Psalm 113 could be regarded as a case in point. The hymn praises the deity for changing the situation of the poor and needy and the childless woman. The poor and needy are elevated to positions of royalty and the barren woman becomes the happy mother of children. Thus, the psalm emphasises the efficacy of Yahweh's intervention on behalf of those who occupy the lowest stratum of society. Given the reversal of the status quo highlighted in Psalm 113, this contribution endeavours to elucidate the song of praise in terms of the cultural phenomenon of mundus inversus (world-upside down). It will be shown that the ubiquity of this topos in various cultures and artistic, religious and socio-political spheres allows for its application to the situation depicted in verses 7-9. The article will offer a discussion on the plight of the poor and the barren woman in ancient Israel. An inversion of the circumstances of social outcasts serves as a form of socio-economic criticism and calls attention to the affliction of those occupying the anti-structure.

\section{A FEW REMARKS ON THE POOR IN THE HEBREW BIBLE}

No doubt, the poor, which were not a homogenous ${ }^{1}$ group, feature prominently in the history of ancient Israel $^{2}$. The legal, prophetic, wisdom, and liturgical traditions all view poverty as a matter of grave significance (cf Pleins 1992:413). Multiple biblical Hebrew references to the poor reveal their identity and the often-appalling conditions they lived $\mathrm{in}^{3}$. The Hebrew Bible frequently mentions the

1 The poor constituted a diverse body of social actors, viz small farmers, day workers, construction workers, beggars, debt slaves and village dwellers (Pleins 1992:402).

2 Compare the statement of Schwantes (1977:278) in this regard: "Der auf Israel ruhende Segen ... seine geschichtliche Existenz ... die seiner Herrscher ... und seine Reichen ... waren immer wieder entscheidend von ihrem Verhalten zu den Kleinen in ihrer Mitte abhängig. Die Armen haben die geschichte des Gottesvolkes in entscheidender Weise mitgestaltet."

3 As far as the meaning of the different biblical Hebrew terms for poor is concerned, see eg the contributions of Mowinckel (1962); Kraus (1966); Cone 
poor as a group vulnerable to exploitation and oppression ${ }^{4}$. It should be noted, however, that the various strands of the biblical texts offer diverging analyses of the circumstances of the poor (cf Pleins: 1992:402). That biblical Hebrew scholars have produced conflicting theories regarding the meaning of the terms for poor should come as no surprise (cf Croft 1987:69).

While the poor person in ancient Israel lacked material needs, he or she could also be regarded as the one "wer rechtlos ist, wer keinen Einfluß und kein Ansehen besitzt, wer unvermögend mächtigen Widersachern ausgeliefert ist" (Kraus 2003a:190). Because these people were destitute, they became social outcasts on whose rights the powerful trampled at will. Socio-economic, juridical and ethical concerns had to be raised to alleviate the plight of the poor. Given their vulnerability, a host of unique laws were introduced to protect the poor against those who constantly tried to abuse and oppress them. Because the poor had no rights (or possibly restricted rights), no legal personalities, they had to be protected against oppressors (Fensham 1962:139). According to Hiers (2002:91), "numerous biblical laws were intended to ensure that particularly vulnerable persons would not be subjected to oppression or discrimination. Other biblical laws called for establishing a variety of institutions ... to assure that persons living on the socioeconomic margins would enjoy ... some measure of freedom from hunger, as well as other types of support or care"s. The ethical imperative to care for the poor was grounded in Yahweh's covenant with his people and became one of the cornerstones of the divinehuman relationship. "Throughout the Old Testament ... the cause of the widow, the orphan, and the poor (my emphasis) is particular enjoined upon Israel as befitting a redeemed people who are

(1975); Pleins (1992); Un-Sok Ro (2000); Levin (2001); Berges (2004) and Tucker (2004).

$4 \quad$ Cf eg Ex 23:6; Prov 22:22, 23; 29:7; 31:9; Isa 3:13-15; 10:1,2; Jer 7:5,6; Zech 7:9,10; Mal. 3:5; Amos 5:12.

5 Compare also the remark of Botterweck (1973:33) in this regard: "Der Schutz des ... sozial Schwachen gehört zur Lebensordnung Israels und findet daher in Geboten, Verboten und weisheitlichen Mahnungen für die Stammesbrüder, insbesondere für die einflußreichen und besitzenden Kreise, seine sozialethische Ausformung." For legal texts concerned with the protection for the poor, cf eg Ex 22:24; 23:10-11; Lev 19:9-10; 25:35-38; Deut 23:20-21; 24:20-21. 
entrusted with the character and standards of their Redeemer" (Patterson 1973:232). A just and ethical God was not satisfied to see the poor suffer and languish in their poverty (Gamoran 1971:128). Not surprisingly, then, any ill-treatment of the poor violated the covenant and brought divine punishment on those responsible.

\section{THE YOKE OF BARRENNESS ${ }^{6}$}

It would not be far-fetched to assume that children were of primary concern to Israelite women and that motherhood was a desired state in ancient Israel. Children brought status, welfare, prestige and social recognition in a society where individual identity was embedded in the group. The best way for a woman to express herself and achieve recognition and personal security was through bearing children, especially boys (cf Brenner 1985:112). Since children guaranteed the continuation and existence of the group, the fertile woman fulfilled the principle of social preservation and continuity. Biblical passages emphasising female fertility and the overcoming of barrenness serve as an ideological sanction to the adaptive strategy of an increased birth rate (Meyers 1989:273) 7 . In a society based on small-scale agriculture where the family constitutes a self-sufficient economic unit each child was a welcome addition to its labour strength (Mendelsohn 1948:38). Women who failed to live up to expectations with regard to producing children suffered a severe loss of social status ${ }^{8}$. Because a barren woman did not fit into the framework of procreation, she was cut off from society fertility wise. Barren women were relegated to the statusless sphere of antistructure and became disenfranchised entities. Only when a woman was able to bear children, was she part of structure, for procreation is a fundamental element of structure ${ }^{9}$. The childless woman ran the

6 On barrenness in the Hebrew Bible cf Gen 18:9-15; 21:1-7; 25:19-28; 30:1-8, 22-24; Jdg 13; 1 Sam 1; 2 Kg 4:8-17.

7 "What does seem clear is that the first concerns, the 'fertility' ones, were what predominated, and rightly so given the fact that it is upon reproductive success that all societies are fully dependent" (Nakhai 2007:520).

8 "... the barren woman suffered immediate social and psychological deprivation for her failure to bear children" (Bird 1997:35). Cf Job 24:21, where a barren woman is mentioned alongside a widow as someone who lacks protection.

9 Malul (2002:373) maintains, "Her very raison d'etre is to be perpetually known, for only then does she fulfil the very basic tenet of structure - that of procreation." 
risk of rejection by her husband and his family and incurred the suspicion of indecent behaviour (Van der Toorn 1994:79) ${ }^{10}$. The fact that the image of a barren woman is one of the strongest images of desolation and rejection in the Hebrew Bible should come as no surprise (cf Ryken et al 1998:75). The notion of wretchedness associated with infertility is also attested in other ancient near eastern literature ${ }^{11}$. One such text is the Epic of Gilgamesh where, as part of their dialogue, Gilgamesh and Enkidu reflect on the status of the barren woman in the netherworld. The situation of a childless woman is described as follows:

Gilgamesh: "Did you see the woman who had not given birth?"

Enkidu: "I saw her."

Gilgamesh: "How does she fare?"

Enkidu: "Like a defective pot she is discarded with force, no man takes pleasure in her."

(As translated by George 2003:775)

To prevent barrenness or to put an end to it, women often took vows or performed rituals (cf Van der Toorn 1989) ${ }^{12}$. In an Akkadian incantation against infertility, a woman expresses her desire for children through the following words:

O pure kiln, great daughter of Anu ... Take away my distress, let no [imperfect vessel] come out of you, So too for me, may what is within me thrive, may I see my baby, may I find acceptance in the house wherein I dwell!

(As translated by Foster 2005:979)

10 Compare the remark of Weiser (1962:708) in this regard "Childlessness was regarded in the ancient Orient as a disgrace and could result in the expulsion of the barren woman from the household or in the diminishing of her privileges" (cf also Teitelbaum 1948:242; De Vaux 1976:4; Van Rooy 1986:225-235; Marsman 2003:224). In ancient Israel, barrenness is even connected to sin (cf Num 5:11-31; 2 Sam 6:20-23).

11 According to Walls (2007:27) "Mythological texts represent an infertile woman as disabled or defective, in one sense or another, because the cultural presumption was that a woman's normative social role was as wife and mother".

12 Cf also Pata (1944) on the different Jewish-folk cures against barrenness. 
The psychological stress resulting from infertility forced barren women to implore the gods to restore their fertility and subsequent social status in society.

\section{INVERSION IN PSALM 113:7-9}

Babcock (1978:14) defines mundus inversus as "any act of expressive behavior which inverts, contradicts, abrogates, or in some fashion presents an alternative to common held cultural codes, values, and norms be they linguistic, literary or artistic, religious or social and political" (my emphasis). It points to the fact that a more or less familiar environment is suddenly arranged in such a way that it contrast the way the world is commonly experienced (cf. Colie 1966:16). According to Stubbe (1988:199), "Der Begriff 'verkehrte Welt' bezeichnet die Umkehrung geltender Zustände. Dieses Motiv ist Weltweit verbreitet, und in fast allen abenländischen Sprachen findet sich hierfür ein eigener Ausdruck"13. Not surprisingly, this topos has been utilised in various cultures to critique existing socioeconomic, socio-political and religious status quos. One could argue that in Psalm 113:7-9, the cultural phenomenon of mundus inversus highlights an idealised socio-economic order ${ }^{14}$. This positive and idealistic notion of the "world-upside down" is often associated with the lowest people in the social hierarchy (cf Mühlmann 1961:618). It stresses the possibility of another reality brought about by an inversion of the status quo. As regards the positive and negative impact of the principle of mundus inversus, Assmann (1993:42) claims, "Sie kann die bestehende Ordnung sowohl relativieren als auch verabsolutieren. Sie führt einmal vor Augen, dass alles auch anders möglich ist, und macht anderseits klar, dass es anders nicht geht, sondern dass die Umkehrung der Ordnung dem Zusammenbruchs des Lebens gleichkommt." Verses 7-9 indicate that Yahweh can suddenly arrange a more or less familiar environment in such a way that it contrasts the way the world is commonly experienced. Psalm 113 is, therefore, a hymn of praise to the deity for his condescension to the socially marginalised. Whereas Westermann (1981:114) and Estes (2005:156) describe it as a psalm

13 Cf also Lazarowicz (1963); Kenner (1967; 1970); Gutwirth 1981; Kramer 1988; Flores (2004); Kruger (2005).

14 Compare the observation of Malul (2002:168), "This psalm builds upon the theme of the 'world-upside down' which is very frequent and seems to touch upon some basic principles of biblical Weltanschauung." 
of descriptive praise because of its simple threefold form ${ }^{15}$, Crüsemann (1969:134-135) is of the opinion that both the elements of hymnal participles and hymnal imperatives can be found in Psalm 113. Despite their different viewpoints, these scholars emphasise an important feature of the psalm, namely the praise offered to the deity for his transformative and restorative deeds ${ }^{16}$.

The pronouncement in verses 5-6 "Who is like Yahweh our God, enthroned so high, looking down so low in heaven or on earth" ${ }^{17}$ has its foundation in the conviction that Yahweh is the one whom Israel encountered in its history, and who from his heights intervenes in the depths of tribulation. (cf Westermann 1981:120). In addition, it celebrates the incomparability of the God of Israel ${ }^{18}$. Two fundamental ideas from the heart of the psalm, both concerned with the nature of Yahweh, namely his incomparable majesty and his no less wonderful compassion on those who are despised among them (Weiser 1962:705; cf also Human 2004:41). From his heavenly abode, the deity looks down into the depths of specific needs (poverty and barrenness). Compare the remark of Kraus (2003 b:952) in this regard, "Gottes Erhabenheit und Macht erweist sich in seinem Erbarmen und in der wunderbaren Erhöhung erniedrigter und geschmähter Menschen." Noteworthy is the fact that Yahweh, who is enthroned in the heavens above ( $\mathrm{vv} 4,5)$, looks down (v 6) to raise up those considered to be amongst the lowest in society, namely the

15 Descriptive psalms of praise comprise (1) a call of praise inviting others in the community to rejoice in Yahweh, (2) the cause for praise cites the goodness and greatness of Yahweh and (3) frequently conclude with an exhortation "Hallelujah" or a more extensive word of instruction (cf Estes 2005:156). Psalm 113 is a psalm of descriptive praise because “... it does not have, like declarative praise, a specific, unique occasion; it is not a confession of the one saved, but it looks at the mighty God's great deeds in all times and in all places and praises him for them all" (Westermann 1981:32).

16 Briggs \& Briggs (1906); Schmidt (1934); Kissane (1954); Weiser (1962); Allen (1983); Gerstenberger (2001) and Kraus (2003b) also highlight the hymnic elements of Psalm 113.

17 Cf Allen (1983:98).

18 According to Human (2004:53), "the question not only sets a challenge to any other god or power, but it provokes a negative answer in order to sketch Yahweh as supreme God. The question is polemically inclined towards any other deity or utterance describing the incomparability of other gods". 
poor and needy and the barren woman (vv 7-9). The deity's heavenly status is echoed in his bestowal of human status (Allen 1983:100).

Psalm 113 praises Yahweh for inverting the worst of circumstances. An inversion of the situation of the poor and needy allows them to move from anti-structure to structure. The first two groups afforded a position in structure are the אביון and ${ }^{19}$. The poor and needy find themselves in the company of nobles. The imagery of inversion highlights Yahweh's transformative power and his concern for the under-privileged. According to Levin (2001:264) "the special relationship of the poor to Yahweh finds its clearest expression in the Psalms"20. These poems depict the deity as the one the poor and needy pray to for protection against their oppressors. As Schwantes (1977:11) observes, "In den Psalmen geht es weitgehend um den betenden, Jahwe suchenden und auf ihn angewiesenen Armen" Psalm 113's focus on the inversion of the situation of the poor and needy highlights the deity's concern for their plight ${ }^{22}$. They are the economic destitute and powerless ${ }^{23}$ members of society (cf Weir 1989:13). These groups, normally social outcasts, are the focus of Yahweh's bold intervention in verses 7-8. Moreover, Psalm 113:7, 8 advance the notion that the vertical conduct of the deity should serve as a model for horizontal relations. The assistance of the afflicted and the change of their situation were set as a general ideal for important and powerful people (cf Fensham 1971:163). As regards the identity of דל אביון in Psalm 113, Botterweck (1973:41) remarks, "Nach dem Kontext gehören die אביון un uל ur Gruppe der Wankenden, Hungernden, Armen und Frommen ..." Moreover, in the Psalms אביון and describe material need and physical poverty and

19 For other contextual settings of the אביון - דל combination, see eg 1 Sam 2:8; Isa 14:30; Amos 4:1; Pss 72:13; 82:4; Prov 14:31; Job 5:15-16.

20 On the poor in the psalms, cf eg Pss 9:13; 12:6; 25:16; 35:10; 37:14; $40: 18 ; 41: 2 ; 69: 34 ; 70: 6 ; 82: 4 ; 107: 41 ; 109: 16,22 ; 132: 15$.

21 Cf also Fabry (1977:241), "Ein feststehendes Motiv in den Psalmen ist die Erhöhung des Geringen und Armen durch JHWH."

22 For other allusions to the lowly be lifted from the dust (cf 1 Sam 2:8; 1 Kg 16:2; Job 5:11).

23 Dickson (1995:1042) also emphasises the notion of powerlessness associated with the poor. 
as such are rendered powerless against exploitation. The' suffered severe economic deprivation, which may have involved homelessness and dependence on alms (Pleins 1992:403). Originally, אביון referred to a beggar and only later was used to designate a poor and/or needy person (Groenewald 2007:434). דל referred to people within the community who lacked physical means but who experienced God's protection because they received care through the community (cf Gillingham 1989:16; Tucker 2004:435). The reference עשפת ("dust") ("rubbish heap") in verse 7 underscores the poverty, desertion and lowliness experienced by the needy and the poor. The repetition of עם-נדיבים ("with princes/nobles") in verse 8 accentuates the privileged position of the poor and needy.

The inversion of the status quo also applies to the barren woman. The notion of the mundus inversus finds expression in such cases as "ultimogeniture, the love for the younger woman, the slave who attains a high status, the foundling who rises to power, as well, perhaps, as stories of barren women who give birth" (my emphasis Malul 2002:478). In Psalm 113:9, Yahweh grants the barren woman the right to become a mother and, as a result, dwell among the fertile women of society ${ }^{25}$. By allowing the barren woman to become the mother of sons, Yahweh brings her back into the scheme of fertility where she can fulfil one of the basic principles of structure, namely procreation. An inversion of the woman's situation is both social and psychological because motherhood brings status, honour, social esteem, security and self-respect. He removes the stigma of childlessness and vindicates a suffering woman. Suffice it to note that a similar notion is attested in an Akkadian prayer where the deity is acknowledged as the one capable of inverting barrenness, "Without you scattered people are not brought together. Where you command so the scorned one gives birth to children ... Whoever has no son you give him an heir. Without you the childless one can receive neither seed nor impregnation" (as translated by Van der Toorn 1994:78). Likewise, in Psalm 113:9 the deity accomplishes

24 Groenewald (2007:433-436) offers an illuminating exposition on אביון. For references to אביון in legal, wisdom and prophetic texts cf. Bosman (1991); Lohfink (1991); Spangenberg (1991); and Van Heerden (1991).

25 Psalm 113:9 echoes the ideal situation expressed in Deut 7:14: "You will be blessed more than any other nation; none of your men or women will be childless ..." 
what is considered impossible and unexpected: a barren woman gives birth. Yahweh's acts are not "inversions and transformation that just anyone could do; they are rather inversions and expectations that lie outside the sphere of anything known, experienced, or expected anywhere else" (my emphasis; Brueggemann 1995:40).

Striking is the utilisation of certain stylistic elements to accentuate Yahweh's power to invert the status quo. The word-play רם (רום: qal, "he is exalted") and (ישבת (ם) "to dwell") in verses 4-5 and ירים (רום: hiphil, "to raise"), ישבושיבי: hiphil, "to make [them] dwell") and מישושיבי (ישב: hiphil, "to make [her] sit, abide") in verses 7-9 accentuate Yahweh's majestic ability to restore the status of the downtrodden. According to Zemek (1993:131) "this exalted One mercifully and characteristically exalts lowly and exasperated people. He who is transcendent enables them to transcend their stifling circumstances". The question in verses 5-6, "Who is like Yahweh our God, enthroned so high, looking down so low in heaven and on earth?" anticipates Yahweh's acts of inversion in verses 7-9. Considering the instances of inversion in vv. 7-9, it could be argued that Yahweh's looking down (ראה] לראות]: to see; v. 6) from above emphasises his care, benevolence and support (cf. Gen 22:8, 14; 1 Sam. 1:11; 2 Sam 16:12; Ps 106:44). Noteworthy in verse 8 is the progression from extrication to exaltation (cf Zemek 1993:145). Yahweh is praised for raising the socially underprivileged to positions of respect and as such bringing about a providential reversal (cf Allen 1983:101). In keeping with Israel's credo, verses 7-9 ascribe the power to elevate or lower to Yahweh. Moreover, they stress the point that just as Yahweh can elevate and transform the poor and needy, so too can He allow the barren woman to give birth and be a happy mother of children (Marcus 1979:82). While ancient near eastern texts ascribe the change of misfortune into fortune to a specific god (cf Fensham 1971:157), biblical Hebrew poetry attributes the power to elevate to Yahweh, the incomparable God (cf Ps 68:7; Job 5:11; 12:18-21; 29:15-16; Isa 61:1). In Psalm 113:7-9 the notion of inversion represents an ideal state of affairs where the poor will no longer be oppressed and exploited and no woman will have to bear the stigma of barrenness.

\section{CONCLUSION}

This contribution explicated Psalm 113 in terms of the cultural phenomenon of mundus inversus, highlighting two instances of a 
positive inversion, namely the poor and needy sitting with nobles and a barren woman becoming a mother. Through an inversion of the presumed world, those who form part of the anti-structure are afforded a position in structure where their honour is restored. Psalm 113 depicts Yahweh as the one who inverts the status quo through acts of transformation and restoration. Not only does an inverted world bear witness to divine care for the socially marginalised but it also serves as a radical claim that conventional notions of reality cannot limit Yahweh's power. No doubt, Psalm 113 proclaims, "the radical transformative power of God, a power at work on behalf of the weak ... a power that is capable of reversing reality and the human situation (my emphasis) from its existing and expected state into a totally different state" (Miller 1986:77).

\section{Consulted Literature}

Allen, L C 1983. Psalms 101-150. Waco, Texas: Wordbooks (WBC).

Anderson, B W 2000. Out of the depths. The psalms speak for us today, $3^{\text {rd }}$ Edition. Louisville, Kentucky: Westminster.

Assmann, J 1993. Literatur und Karneval in Alten Ägypten, in: Döpp, S (Hrsg), Karnevaleske Phänomene in antiken und nachantiken Kulturen und Literaturen. Bochumer Altertumswissenschaftliches Colloquium 13, 31-57: Trier.

Babcock, B 1978. Introduction to the reversible world. Symbolic inversion in art and society. Itchaca: Cornell University Press.

Berges, U 2004. God Staat aan de Kant van de Armen (Ps. 109, 31). Tijdschrift voor Theologie 44, 108-123.

Bird, P A 1997. Missing persons and mistaken identities. Women and gender in ancient Israel. Minneapolis: Fortress Press.

Bosman, H L 1991. "So iets word nie in Israel gedoen nie". Die regspraak in oud-Israel, in Bosman, HL et al (red), Purper en flenterlap. Rykdom en armoede in die Ou Testament, 202-219. Pretoria: J L van Schaik.

Botterweck, G J 1973. Art. אביון. ThWAT I, 28-43.

Brenner, A 1985. The Israelite woman. Social role and literary type in biblical narrative. Sheffield: Sheffield Academic Press.

Briggs, C A \& Briggs, E G 1906. The Book of the Psalms II. Edinburgh: T\&T Clark (ICC).

Brueggemann, W 1995. The Psalms and the life of faith. Minneapolis: Fortress Press.

Colie, R L 1966. Paradoxia epidemica. The renaissance tradition of paradox. Princeton: Princeton University Press.

Cone, J H 1975. The God of the oppressed. New York: Seabury Press. 
Croft, S J L 1987. The identity of the individual in the psalms. Sheffield: Sheffield Academic Press (JSOT SS44).

Crüsemann, F 1969. Studien zur Formgeschichte von Hymnus und Danklied in Israel. Neukirchen-Vluyn: Neukirchener Verlag.

De Vaux, R 1976. Ancient Israel. Its life and institutions. London: Darton.

Dickson, C R 1995. The Hebrew terminology for the poor in Psalm 82. HTS 51(4), 1029-1045.

Estes, D J 2005. Handbook on the wisdom books and psalms. Grand Rapids: Baker Academic.

Fabry, H-J 1977. Art. דל. ThWAT II, 221-244.

Fensham, F C 1962. Widow, orphan, and the poor in ancient Near eastern legal and wisdom literature. Journal of Near Eastern Studies 21(2), 129-139.

-, 1971. The change of the situation of a person in the ancient Near eastern and biblical wisdom literature. Annali Dell'Instituto Orientale di Napoli (AION) $31,155-164$.

Flores, D 2004. The topsy-turvy world, in Knoppers, GN (ed), Egypt, Israel, and the ancient Mediterranean world. Studies in honor of Donald $B$. Redford, 233-255. Leiden: Brill.

Foster, B R 2005. Before the muses. An anthology of Akkadian literature, $3^{\text {rd }}$ edition. Bethesda, Maryland: CDL Press.

Gamoran, H 1971. The biblical law against loans on interest. Journal of Near Eastern Studies 30, 127-134.

Gerstenberger, ES 2001. Psalms (Part 2) \& Lamentations. Grand Rapids, Michigan: William B Eerdmans (FOTL 15).

Gillingham, S 1989. The poor in the Psalms. Expository Times 100, 15-19.

George, A R 2003. The Babylonian Gilgamesh epic. Introduction, critical edition and cuneiform texts, Vol. II. Oxford: Oxford University Press.

Groenewald, A 2007. Psalms 69:33-34 in the light of the poor in the Psalter as a whole. Verbum et Ecclesia 28 (2), 425-441.

Gutwirth, E 1981. The world upside down in Hebrew. Orientalia Suecana XXX, 141-147.

Hiers, R H 2002. Biblical social welfare legislation. Protected classes and provisions for persons in need. Journal of Law and Religion 17(1-2), 49-96.

Human, D J 2004. Yahweh, the Israelite high God bends down to uplift the downtrodden. Perspectives on the incomparability of Yahweh in Psalm 113. Journal of Northwest Semitic Languages 30(1), 41-64.

Kenner, H 1967. Das Phänomen der verkehrten Welt in der klassischen Antike. Forschungen und Fortschritte 41, 11-14.

-, 1970. Das Phänomen der verkehrten Welt in der griechisch-römischen Antike. Klagefurt: Habert Verlag. 
Kissane, E J 1954. The Book of the Psalms II (73-150). Dublin: Richview Press.

Kramer, F 1988. Verkehrte Welten. Zur imaginären Etnographie des 19. Jahrhunderts. Frankfurt: Syndikat.

Kraus, H-J 1966. Worship in Israel. A cultic history of the Old Testament. Translated by G Buswell. Richmond: John Knox Press.

-, H-J 2003a [1978]. Psalmen 60-150 (7. Auflage). Neukirchen-Vluyn: Neukirchener Verlag (BKAT XV/2).

-, 2003b [1979]. Theologie der Psalmen (3. Auflage). Neukirchen-Vluyn: Neukirchener Verlag (BKAT XV/3).

Kruger, P A 2005. Symbolic inversion in death. Some examples from the Old Testament and the ancient near eastern world. Verbum et Ecclesia 26 (2), 398-411.

Lazarowicz, K 1963. Verkehrte Welt. Vorstudien zu einer Geschichte der deutschen Satire. Tübingen: Niemeyer.

Levin, C 2001. The poor in the Old Testament. Some observations. Religion and Theology 8 (3-4), 253-273.

Lohfink, N 1991. Poverty in the laws of the ancient Near East and of the Bible. Theological Studies 52, 34-50.

Malul, M 2002. Knowledge, control and sex. Studies in biblical thought, culture and worldview. Tel Aviv: Jaffa.

Marcus, D 1979. The barren woman of Psalm 113:9 and the housewife. An antiphrastic dysphemism. Journal of the Ancient Near East Society of Columbia University 11, 81-84.

Marsman, H J 2003. Women in Ugarit and Israel. Their social and religious position in the context of the ancient Near East. Leiden: Brill.

Mendelsohn, I 1948. The family in the ancient Near East. Biblical Archaeologist 11 (2), 24-40.

Meyers, C 1989. Women and the domestic economy of early Israel, in Lesko, BS (ed), Women's earliest records from ancient Egypt and western Asia, 265-282. Atlanta: Scholars Press.

Miller, P D 1986. Interpreting the Psalms. Philadelphia: Fortress Press.

Mowinckel, S 1962. The Psalms in Israel's worship. Translated by DR ApThomas. Oxford: Basil Black.

Mühlmann, W E 1961. Das Mythologem von der verkehrten Welt. Kölner Zeitschrift für Soziologie und Sozialpsychologie 13 (4), 614-624.

Nakhai, B A 2007. Gender and archaeology in Israelite religion. Religion Compass 1 (5), 512-528.

Pata, R 1944. Jewish folk-cures for barrenness. Folklore 55 (3), 117-124.

Patterson, R D 1973. The widow, orphan, and the poor in the Old Testament and the extra-biblical literature. Bibliotheca Sacra 130, 223-234. 
Pleins, J D 1992. Art, Poor, Poverty. ABD 5, 402-414.

Ross, A P 1985. Psalms, in: Walvoord, JF \& Zuck, RB (ed), The Bible knowledge commentary I, 779-899. Wheaton: Victor.

Ryken, L et al 1998. Dictionary of biblical imagery. Downers Grove, Illinois: Intervarsity Press.

Schmidt, H 1934. Die Psalmen. Tübingen: JCB Mohr (HAT 15).

Schwantes, M 1977. Das Recht der Armen. Frankfurt am Main: Peter Lang (Beiträge zur biblischen Exegese und Theologie 4).

Spangenberg, I J J 1991. "Die armes sal julle altyd by julle hê". Rydom en armoede vanuit 'n wysheidsperspektief, in Bosman, HL et al (red), Purper en flenterlap. Rykdom en armoede in die Ou Testament, 243-262. Pretoria: JL van Schaik.

Stubbe, H 1988. Trauerverhalten und das Phänomen der verkehrten Welt. Zeitschrift für Ethnologie 113, 199-205.

Teitelbaum, I 1948. Two cases of psychogenic sterility in the Bible. The Journal of Sex Research 4 (3), 242-246.

Tucker, W D 2004. A polysemiotic approach to the poor in the Psalms. Perspectives in Religious Studies 31, 425-439.

Un-Sok Ro, J 2000. Die sogenannte 'Armenfrömmigkeit' im nachexilischen Israel. Berlin: De Gruyter.

Van der Toorn, K 1989. Female prostitution in payment of vows in ancient Israel. Journal of Biblical Literature 108 (2), 193-205.

-, 1994. From her cradle to her grave. The role of religion in the life of the israelite and the babylonian women. Sheffield: Sheffield Academic Press.

Van Heerden, W 1991. Profete en profytmakers. Profetiese perspektiewe op rykdom en armoede, in Bosman, HL et al (red), Purper en flenterlap. Rykdom en armoede in die Ou Testament, 220-242. Pretoria: JL van Schaik.

Van Rooy, H F 1986. Fertility as blessing and infertility as curse in the ancient Near East and the Old Testament, in Bonanno, A (ed), Archaeology and fertility cult in the ancient Mediterranean, 225-235. Amsterdam: B R Grüner.

Walls, N H 2007. The origins of the disabled body. Disability in ancient Mesopotamia, in Avalos, $\mathrm{H}$ et al (eds), This abled body. Rethinking disabilities in biblical studies, 13-30. Atlanta: Society of Biblical Literature.

Weir, J E 1989. The poor are powerless. Expository Times 100, 13-15.

Weiser, A 1962 [1959]. The Psalms (Translated by H Hartwell). London: SCM Press.

Westermann, C 1981 [1961]. Praise and Lament in the Psalms (Translated by K R Crim \& R N Soulen). Atlanta: John Knox Press.

Zemek, G J 1993. Grandeur and grace. God's transcendence and immanence in Psalm 113. The Master's Seminary Journal 1, 129-148. 